\title{
Editorial
}

\section{Farewell to Springer Publishing}

This is the 48th and final regular issue of International Psychogeriatrics to be produced by Springer Publishing since the first appearance of the journal in 1989. There have also been several popular supplements. It is time to say farewell and thank you to the publishing company that helped to inaugurate what I and my colleagues on the editorial panel hope is and will be the preeminent peerreviewed journal devoted to the mental health of older people.

Back in the late 1980s, it took vision and courage for a publishing company to take the leap of faith inherent in agreeing to the proposal of the International Psychogeriatric Association (IPA) to inaugurate the second peer-reviewed journal of its type, the International Journal of Geriatric Psychiatry having been launched by John Wiley of Chichester, UK, in 1986. Fortunately, Ursula Springer and her colleagues had the foresight and commitment to accept the proposal worked out by Manfred Bergener and Sandy Finkel for a twice-yearly journal to be sent to members of IPA and marketed to relevant institutions and libraries. Now after a decade and a half, IPA is thoroughly established as the peak international organization in the field, the journal has long been listed in Index Medicus and other abstracting services, and we were advised in June that it was accorded an impact factor of 1.118 for 2002 in the Institute for Scientific Information Journal Citation Reports (this editorial was nearly titled Habissimus Impact Factor!). Our field has grown and deepened and the existence of this journal as a vehicle for research publication, opinion, and debate has played a significant role in that rapid development.

In 2002 , in line with its policy of soliciting competitive bids for all outsourced aspects of IPA's operations, the IPA Secretariat circulated a request for proposals to publish International Psychogeriatrics for the period 2004-2006. A series of excellent bids was received-interest in the proposal from a number of publishing companies was a measure of the significance of psychogeriatrics and the esteem in which IPA is held. That in a crowded and competitive field another bidder was preferred to Springer is now a 
matter of record, but reflected the very high quality of all bids rather than any deficiency in Springer's.

As this journal and Springer diverge to travel their separate paths, I wish to thank our publisher and all the staff who are and have been associated with the production of this journal for their commitment, integrity, and helpfulness that have characterized their relations with me in my time as Book Review Editor, Deputy Editor, and Editor-in-Chief.

David Ames

Editor-in-Chief

Melbourne, Australia 